\title{
A Study on the Effectiveness of the Equity Incentive Plan of Zhuhai Private Enterprises: Based on the Case of Livzon Group
}

\author{
QiTong $\mathrm{Yu}^{1}$, WenYu Dong ${ }^{1}$ \\ ${ }^{1}$ Finance Department of International Business School, Jinan University, China \\ Correspondence: WenYu Dong, Finance Department of International Business School, Jinan University, China.
}

Received: March 22, 2018

doi:10.11114/aef.v5i3.3127

\author{
Accepted: April 8, $2018 \quad$ Available online: April 10, 2018 \\ URL: https://doi.org/10.11114/aef.v5i3.3127
}

\begin{abstract}
Stem from the United States of 1950s, equity incentive plan was introduced into China as a method for enterprises to solve the principal-agent problem and to motivate key technical staffs to speed up innovation after reform and opening-up. This article is divided into three main parts. Firstly a broad introduction to all the Zhuhai enterprises that have carried out the equity incentive plan and analysis on their implementation from five different perspectives, namely rate of progress 、industry distribution 、 pattern、 source of stock and the period of validity. Then based on the case of Livzon Group, we conduct survey on both its financial performance and non-financial performance and discuss the effectiveness of its plan by data analysis, according to which we could draw a conclusion that the equity incentive plan works well in Livzon Group, then we continue a further study on the reason behind it. In the last part, feasible policy suggestion is provided from respectively government and enterprise side on the basis of the analysis of the former two parts.
\end{abstract}

Keywords: equity incentive, stock option, restricted stock, Livzon Group

\section{Introduction}

\subsection{Implication of Stock Incentive}

The equity incentive plan was originated in the United States of 1950s. In this plan, the stocks of the listed company are presented to the core management personnel and technicians to motivate these stuffs to run the company with a role of shareholder. It is a plan that urges the key staffs to share benefits and take risks with all the shareholders and that based on the ultimate objective of owners' wealth maximization.

\subsection{Significance of Stock Incentive}

Equity incentive plan was born under the background of corporate system. In incorporated enterprises, the shareholders entrust managers to manage the assets of company. Under the premise of bearing certain amount of costs and risks, the manager endeavor to maximize return per unit of stockholders' equity. But because of the separation of owners and managers, the adverse selection and moral hazard are caused by asymmetric information, making the management and decision-making of company managers deviate from the shareholders' goals to a certain extent and resulting in the principal-agent problem. Equity incentive plan can not only address the principal-agent problem as well as prevent adverse selection and moral hazard problem, but also retain key talents and promote their creativity and work enthusiasm. Engaging employees in the company's operating decision and combining their interest with the interest of the enterprise can encourage them to set their working objectives more than just the current salary and bonus, but the long-term development and business performance of the company. As shareholders, employees can attain huge bonus if the company performs well because they have the ownership and right of control. As investors, they can also earn a fat profit by selling stocks of companies with great prospect on the secondary market, the stocks that show as price rising and increasing holdings by the institutions.

\subsection{Pattern of Stock Incentive}

Date back to 1950s when the equity incentive plan was invented, China had already carried out the reform and opening-up policy, and the enterprises had imported lots of excellent operation patterns of foreign enterprises and of classic management cases. After that, the equity incentive plan, including the virtual stock model, the stock option model, the restrictive stock model and the stock value added right model, had obtained rapid promotion throughout 
China's private enterprises. Among all those models, the stock option and restricted stock has been widely applied in the private listed company of China.

The stock option is a right given to the encouraging object by the listed company to buy a certain amount of unlisted stock at a specific strike price on a specified date. The encouraging objects can exercise this right within a limited time, or choose to give up this power. Generally, there will be a one-year waiting period when the stock ownership plan takes effect, and the stock options can only be executed when they are expired.

The restricted stock is a set of stocks that the listed company presents to the encouraging objects who can obtain the stock at a lower cost. The lock-up period of restricted stock is often 1 to 3 years. Upon satisfaction of certain conditions (restrictions), the stock is no longer restricted, and becomes transferable to the person holding the award. This is a kind of stock ownership plan that the right equals the obligation.

\section{Literature Review}

The validity of equity incentive has long been the focus of controversy in academia. Holmstrom (1979) believed that if the company's shareholders can identify the operator's business management activities, then the use of a fixed payment and the punishment for violations of the operator can ensure that the operators work hard to create maximum value for shareholders. However, due to the separation of ownership and control rights of modern company system, the agency problem between the shareholders and the management layer arises, which means that the shareholders generally cannot fully supervise the operators' actions, nor do they know whether the operators' efforts is optimal. As a result, more scholars are concerned about the relationship between the design of the equity incentive contract structure and failure of the company's operation.

Palia and his fellows considered that the stock holding of senior managers is beneficial to reduce the fraudulent behavior in the company's decision making, and it is more advantageous for the managers to keep their eyes long and to pay more attention to the growth of enterprises so as to serve the enterprises better (D Palia \& F Lichtenberg, 1999). Aboody and others conducted research on the financial data from 1990-1996 of 1773 listed companies, and the results show that the financial profit index of the company with equity incentive method is higher than that of the company without the use of equity incentive, and the profit index of companies with equity incentive plan is also above the industry average level. Christoph Kaserer and Benjamin Moldenhauer (2012) selected the German automobile manufacturing enterprise as the research object and proved that the equity incentive promotes the company's product sales, with the profit improved and the stock price rising. Wenzhong Zhang (2016) collected data of 97 A shares listed companies that implemented equity incentive in 2006-2010 and constructed a multivariate regression model. The results show that equity incentive is positively correlated with the performances of enterprises.

However, there are also studies showing that there is no significant correlation or even the opposite conclusion between equity incentive and firm performance. Biao Chen and Jianwen Li (2015) pointed out that China's equity incentive system would have positive effect on the performance of enterprises only at an early stage and later this promotion would weaken. Ming Li and Xia Huang (2017) analyzed the effect of equity incentive and the influence of external variables on the effect. The results show that there is a significant increase in corporate performance (net profit growth) after implementation of the equity incentive plan in Chinese listed companies. Equity incentive on employees can have positive effect on the performance of listed companies, but this effect is more significant to private enterprises and small-scale enterprises. As for state-owned enterprises and large-scale enterprises, the effect is not obvious. Jinping Shi and his fellows used the 43-a-share SME companies that implemented equity incentive plan for the first time in 2011 as samples for study, and found that the actual incentive effect of the equity incentive plans on these companies is not obvious (Jinping Shi \& Jili Liu \& Ying Hu, 2014). After a study on the companies that had implemented equity incentive plans on ordinary employees, Paul Oyera and Scott Schaefer (2012) finally summarized that to implement the equity incentive policy on the ordinary employees would not improve the company's performance, but would virtually increase the cost of the company, indicating that there exists a negative correlation trend between the two. Carl Shen (2013) chose 843 companies as samples and found that companies with higher equity incentive levels received lower stock abnormal returns and business performance.

Based on the research on the structure of the Western Equity incentive contract, Domestic scholar Hao Liu \& Sun Yu (2009) pointed out that it is not enough to study the relationship between the equity incentive and the company's performance directly and there is no feasible and effective theoretical framework to explain the using of enumeration method to study the influence factors. Therefore, it is necessary to study the mechanism of equity incentive from the micro-level in order to find out the effect of equity incentive on corporate performance. Based on the above analysis, this article embarks from the Microcosmic enterprise level, using the equity incentive plan of the Livzon Group as an example, to analyze the validity of equity incentive plan and to figure out how the equity incentive influences the performance of the company from two dimensions: the financial situation and the market performance, in order to make contributions to the study of principal-agent theory and the compensation contract mechanism and to provide 
micro-theoretical support for the existing empirical research conclusions.

\section{Area Descriptions}

\subsection{Progress Analysis of the Implementation of the Stock Ownership Plan of Zhuhai Private Listed Enterprises}

The stock incentive system appeared in America in 1950s and was introduced to Asia in 1990s. Measures on Administration of Equity Incentive for Listed Companies were issued by China's Securities Regulatory Commission and SASAC on 1st January 2006, providing policy guidance and operation specifications for the construction of equity incentive mechanism of China's listed companies. Then equity incentive developed quickly in China. As the frontier region of reform and opening-up, Zhuhai has a unique geographical advantage and is supported by the national policy. This is why Zhuhai had introduced and applied the equity incentive pattern from foreign countries at a rather early time. During nearly 12 years from 1st December 2005 to 15 th October 2017, there are altogether 22 private listed companies having published relatively normative drafts of equity incentive plan. Among the 22 companies, about 10 have already taken the plan into effect, accounting for $45.45 \%$. And 7 of the 22 companies had made their draft resolution passed but yet haven't carried out the plan, taking up a proportion of $31.82 \% .3$ companies' equity incentive plans are still remain at the board planning stage with a proportion of $13.64 \%$. Only 2 companies had ceased their equity incentive plan accounting for about $9.09 \%$ of the 22 companies. Such a high rank of implementation indicates that under the guidance of relevant regulations of the state, Zhuhai private listed companies had actively introduced the management method and incentive pattern of foreign enterprises to promote innovations of management patterns and the operating efficiency.

\subsection{Industry Distribution}

Table 3.1. Industry Distribution

\begin{tabular}{lll}
\hline Industry & Sample size & Proportion (\%) \\
\hline Pharmaceutical manufacturing industry & 2 & 9.09 \\
Electrical machinery and equipment & 2 & 9.09 \\
manufacturing industry & & \\
Computer, communications and other electronic & 2 & 9.09 \\
equipment manufacturing industry & 5 & 22.73 \\
Software and information technology services & 1 & 4.55 \\
Food manufacturing industry & 3 & 13.64 \\
Special equipment manufacturing industry & 1 & 4.55 \\
Business service industry & 3 & 13.64 \\
Chemical raw materials and chemical products & 3 & 4.55 \\
manufacturing & 1 & 4.55 \\
Rubber and plastic products industry & 1 & 4.55 \\
Internet and related services & 1 & 100 \\
General equipment manufacturing industry & 22 & in total (according to \\
Total
\end{tabular}

The equity incentive plan of Zhuhai private listed companies involves 11 industries in total (according to Industry classification standard of CSRC). Among these industries, up to as many as 5 companies belong to the Software and information technology services industry, taking up a proportion of $22.73 \%$. Reasons could be that the high-tech industry is a talent-intensive industry and the completion within the industry is fierce. This means that companies hope to retain key technicians and make employees' interest in accordance with the company's interest by the equity incentive plan, believing that this could arouse workers' working motivation and awareness of innovation and therefore could steadily improve the company's core competitiveness. Industry with the second large proportion that the listed companies belonging to is the Special Equipment Manufacturing Industry and the Chemical Raw Materials and Chemical Products Manufacturing Industry, accounting for $13.64 \%$ of all industries. These are also knowledge-intensive and technology-intensive industries, which rely on the continuous research and development of their core technicians and transformation of technological achievements to form core intellectual property rights of enterprises and to push enterprises into industrial operation quickly.

\subsection{Pattern Distribution}

Patterns of stock incentive include stock option, restricted stock, stock appreciation rights and phantom stock, etc. The stock option and restricted stock are most commonly applied in China. In the meantime, different regions make the most suitable equity incentive plan for themselves according to both the external and internal influences. External influences include geographical distribution, resources and industry distribution. And internal influences include structure of personnel, cost of implementation and risk preference. 
Table 3.2. Pattern Distribution

\begin{tabular}{lll}
\hline Pattern & Sample size & Proportion $(\%)$ \\
\hline Stock option & 6 & 27.27 \\
Restricted stock & 13 & 59.09 \\
Mixed model & 3 & 13.64 \\
Total & 22 & 100 \\
\hline
\end{tabular}

From table 3-2, we can see that among all the private listed companies, up to 13 of them choose restricted stocks as the pattern of their equity incentive plan, accounting for $59.9 \%$ of all the patterns. Once the restricted stocks are presented to the encouraging object, they become transferable on the secondary market only after their owners achieve the predesigned performance index. As a result, the implementation of restricted stock should be based on a good performance and prospect of the company, as well as a sound corporate governance structure, which are all premises for a company to effectively stimulate its employees' enthusiasm for independent innovation and to improve its science and technology innovation capability. What's more, there are 3 companies applying mixed model, which is about $13.64 \%$ of those of the 22 companies, as the pattern for their incentive plans. It shows that there is still room for innovation and practice of the governance model of Zhuhai private listed companies.

\subsection{Source of Shares}

There are three main sources of stocks for our country's listed companies to carry out equity incentive plan. They are respectively directional private placement, shareholders' transfer and repurchase from secondary market. In some listed companies, the diversity of the patterns of their equity incentive plans leads to the diversity of the resources of the stocks.

Table 3.3. Source of Shares

\begin{tabular}{lll}
\hline Source of stock & Sample size & Proportion $(\%)$ \\
\hline Directional private placement & 13 & 59.09 \\
Shareholder transfer & 7 & 31.82 \\
Mixed source & 2 & 9.09 \\
Total & 22 & 100 \\
\hline
\end{tabular}

According to table 3-3, the stocks that Zhuhai private listed companies apply in their equity incentive plan are mainly from directional private placement, with 13 of the sample companies applying taking up $59.09 \%$, followed by shareholders' transfer, accounting for $31.82 \%$. Companies with a mixed stock resource are Patel and Yuanguang. Their stocks are respectively from a mixture of shareholders' transfer and directional private placement and a mixture of directional private placement and repurchase from secondary market. In conclusion, directional private placement turns out to remain the most popular kind of stock resources. Reason could be that it cost less than the other resources, such as repurchase from the secondary market which is supported by a large sum of funds. However, the directional private placement would dilute shareholders' shareholding ratio and particularly do harm to large shareholders who have control over the company, while repurchase from secondary market wouldn't bring about such problems because it wouldn't change the shareholding ratio but the shareholding structure.

\subsection{Validity Period Distribution}

Generally, the stock incentive in the listed companies of our country will expire in 4 to 5 years. If the validity period is too short, there will be no long-term incentive effect and the encouraging objects may even cheat to achieve the performance index. But too long of the period will also lead to troubles in predicting the company's development trend and orientation in the future, which is harmful to the setting of suitable performance index.

Table 3.4. Validity Period Distribution

\begin{tabular}{lll}
\hline Validity period & Sample size & Proportion $(\%)$ \\
\hline unsure & 7 & 31.82 \\
3-tear & 2 & 9.09 \\
4-year & 7 & 31.82 \\
5-year & 6 & 27.27 \\
Total & 22 & 100 \\
\hline
\end{tabular}

Data from table 3-4 shows that 7 listed companies of all the sample companies set their validity period as 4 years, which form the largest proportion namely $31.82 \%$. The second largest proportion, which is $27.27 \%$, is taken up by 5 -year validity period. There are 7 companies' validity period is unsure, among which 3 companies remain at board planning stage, 3 companies' equity incentive plans have passed resolution of shareholders' meeting but have not yet put into effect, 1 company has already implemented the equity incentive plan. Reason for the uncertain validity period could be that the companies need to adjust its validity period according to the practical situation to achieve long-term incentive effect. 


\section{Methods}

Livzon Pharmaceutical Group Inc., founded in 1985, is a comprehensive pharmaceutical enterprise integrating development and research, production and sales of pharmaceutical products. With its headquarters building located in Zhuhai, the registered capital of Livzon Group is 533 million yuan. After finishing reform of its shareholding system, Livzon Group became the first A and B shares listed companies in the pharmaceutical industry in china.

Livzon Group is committed to independent research and development, production and sales of Chinese herbal medicine material, medicine and traditional Chinese medicine, medicinal cosmetics, health products and biochemical drugs. All the 53 production lines are compliant with GMP requirements and the marketing enterprise has successfully passed the national GSP certification. The group has showed up in the investment top 10 and management top 10 of Chinese listed enterprises, and comprehensive strength top 50 of the Guangdong pharmaceutical industry. Innovation is Livzon Group's core concept, which is aiming at increasing R\&D investment, continuously improving the quality of products and launching products with core competitiveness to maintain its advantages.

Modern corporation system separates enterprise ownership from managerial authority, leading to the principal-agent problem. The principle-agent problem is a dilemma exists in circumstances where agents are motivated to act in their own best interests contrast to those of their principals, and is an example of moral hazard and adverse selection under information asymmetry.

Livzon Group drafted the Restricted A Shares Incentive Scheme in 2004, and formally implemented it in 2005. The shares under the Scheme comprise the Company's A Shares to be issued to the Incentive Participants. Under the Scheme, Restricted Shares of 10,000,000 A Shares will be granted to the Incentive Participants, representing 3.38\% of the Company's 295,721,852 total number of Shares when the Scheme is signed, among which 9,000,000 shares will be granted initially, representing $3.04 \%$ of the Company's total number of Shares and $90 \%$ of the total number of Restricted Shares to be granted, and 1,000,000 shares will be reserved, representing $0.34 \%$ of the Company's total number of Shares and 10\% of the total number of Restricted Shares to be granted. The Validity Period of the Scheme shall commence on the Date of Grant of Restricted Shares and end on the date on which all the Restricted Shares granted have been unlocked or otherwise repurchased and cancelled, with the longest period no more than 5 years. Incentive Participants under the Scheme shall be the Company's directors, mid and senior-level management, core technical (business) personnel, and relevant staff eligible for incentives in the opinion of the Board, but excluding independent directors and supervisors, add up to 484 participants.

The Date of Grant is on 11th November 2015. The price of initially granted Restricted Shares shall be RMB25.20 per share, at which the Incentive Participants may purchase the Restricted Shares of the Company specially issued to them after the conditions for granting are met. Restricted Shares shall be locked up immediately upon granting. The Restricted Shares granted under the Scheme shall have 12 months Lockup Period commencing from the date of grant. During Lockup Period the granted Restricted Shares are non-transferrable on the secondary market. The unlock arrangement for initially granted Restricted Shares is set out as below:

Table 4.1. Unlock Arrangement

\begin{tabular}{ccl}
\hline Unlock Arrangement & $\begin{array}{c}\text { \% of unlock Shares to the total } \\
\text { Restricted Shares granted }\end{array}$ & \multicolumn{1}{c}{ Duration } \\
\hline First unlock period & $40 \%$ & $\begin{array}{l}\text { Commencing from the first trading day after expiry of the } \\
\text { 12-month period from the initial Date of Grant and ending } \\
\text { on the last trading day of the 24-month period from the } \\
\text { Date of Grant } \\
\text { Commencing from the first trading day after expiry of the } \\
\text { 24-month period from the initial Date of Grant and ending } \\
\text { on the last trading day of the 36-month period from the } \\
\text { Date of Grant } \\
\text { Commencing from the first trading day after expiry of the } \\
\text { 36-month period from the initial Date of Grant and ending } \\
\text { on the last trading day of the 48-month period from the } \\
\text { Date of Grant }\end{array}$ \\
Third unlock period & $30 \%$ & $30 \%$
\end{tabular}

The conditions for unlocking include performance target at company's level and requirements for individual performance. The "growth rate of net profit" shall be calculated on the basis of the net profit attributable to the Shareholders of the listed company after the deduction of non-recurring gains and losses. For the initially granted Restricted Shares, the performance targets for the respective year are specified as follows: 
Table 4.2. Performance Targets

\begin{tabular}{cl}
\hline Unlock period & \multicolumn{1}{c}{ Performance target } \\
\hline First unlock period & $\begin{array}{l}\text { On the basis of the Company's net profit in 2014, the growth rate of } \\
\text { net profit in 2015 shall not be lower than 15\%; }\end{array}$ \\
On the basis of the Company's net profit in 2014, the growth rate of \\
necond unlock period & $\begin{array}{l}\text { On profit in 2016 shall not be lower than 38\%; } \\
\text { On the basis of the Company's net profit in 2014, the growth rate of } \\
\text { the net profit in 2017 shall not be lower than 73\%. }\end{array}$ \\
\hline
\end{tabular}

During the Lock-up Period, both the net profit attributable to the Shareholders of the Company and the net profit attributable to the Shareholders of the Company after the deduction of non-recurring gains and losses shall not be lower than the average amount in the recent three accounting years prior to the Date of Grant and shall not be negative. If the conditions for unlocking are not satisfied in the period, the Company shall repurchase and cancel the Restricted Shares that can be unlocked during that year pursuant to the Scheme.

At individual level, if the performance of an Incentive Participant in the last year is $\mathrm{A} / \mathrm{B} / \mathrm{C}$, the performance of such an Incentive Participant shall be deemed as "pass" and such an Incentive Participant may unlock the corresponding proportions that can be unlocked by that individual Incentive Participant according to the performance result in the last year. If the performance of an Incentive Participant in the last year is D, the performance of such Incentive Participant shall be deemed as "fail", Company will, pursuant to the Scheme, repurchase and cancel the proportions of Restricted Shares granted to the Incentive Participant that may be unlocked during that period.

\section{Results}

\subsection{Financial Situation}

Livzon Group announced its Restricted A Shares Incentive Scheme on October 2015, and the Date of Grant is on 12th November 2015. The first unlock period expired on 11th November 2016, and 171 employees had fulfilled the performance appraisal standard, unlocking 498,560 of the limited sale stock share (account for $0.12 \%$ of the total share capital of the company). The employees who failed the repurchase appraisal would be granted restricted stock. Table 5-1 shows comparison of financial indicators between the year of 2014, 2015 and 2016.

Table 5.1. Financial Situation

\begin{tabular}{|c|c|c|c|c|}
\hline Financial index & Year & 2016 & 2015 & 2014 \\
\hline Working capital & Livzon & $\begin{array}{l}2.66 \text { billion } \\
\text { yuan }\end{array}$ & $\begin{array}{l}430 \text { million } \\
\text { yuan }\end{array}$ & 500 million yuan \\
\hline Liquidity ratio & Livzon & 1.80 & 1.31 & 1.82 \\
\hline Quick ratio & Livzon & 1.47 & 0.82 & 0.87 \\
\hline Currency ratio & Livzon & $62.28 \%$ & $25.30 \%$ & $26.81 \%$ \\
\hline Asset-liability ratio & Livzon & $32.52 \%$ & $40.45 \%$ & $44.10 \%$ \\
\hline Equity multiplier & Livzon & 1.48 & 1.68 & 1.79 \\
\hline Times interest earned & $\begin{array}{l}\text { Livzon } \\
\text { Livzon }\end{array}$ & $\begin{array}{c}18672.6787 \\
5.63\end{array}$ & 3069.86 & 3260.32 \\
\hline Receivable turnover & $\begin{array}{l}\text { Mean of } \\
\text { industry }\end{array}$ & 521.09 & 5.69 & 5.22 \\
\hline & Livzon & 0.82 & & \\
\hline Total assets turnover & $\begin{array}{l}\text { Mean of } \\
\text { industry }\end{array}$ & 0.82 & 0.86 & 0.80 \\
\hline $\begin{array}{c}\text { Net profit margin on } \\
\text { sales }\end{array}$ & $\begin{array}{l}\text { Livzon } \\
\text { Mean of } \\
\text { industry }\end{array}$ & $\begin{array}{c}10.85 \% \\
-106.10 \%\end{array}$ & $9.96 \%$ & $9.99 \%$ \\
\hline Return on equity(ROE) & $\begin{array}{l}\text { Livzon } \\
\text { Mean of } \\
\text { industry }\end{array}$ & $\begin{array}{l}15.48 \% \\
7.22 \%\end{array}$ & $15.51 \%$ & $14.66 \%$ \\
\hline $\begin{array}{l}\text { Return on total } \\
\text { assets(ROA) }\end{array}$ & Livzon & $8.92 \%$ & $8.58 \%$ & $7.98 \%$ \\
\hline
\end{tabular}

Livzon Group raised funds by private placement of A share in 2016, which caused the proportion of shareholders' equity in the total assets to raise. Although the Liquidity ratio didn't show a rapid increase, there was a huge improvement in the Quick ratio and the Currency ratio. With the Slower-changing inventories have decreased compared to the faster cash money, the short-term solvency of Livzon Group has been greatly improved.

The year after the Restricted A Shares Incentive Scheme being adopted, the Livzon company reduced the loan to the bank and had its interest expenses cut. There was a slight decrease in the Asset-liability ratio and the Equity multiplier, 
while the Times interest earned increased obviously from 3069.86 in 2015 to 18672.6787 in 2016 (about six times over). These were results of the joint effect of the reduction of the interest cost and the significant improvement of the performance index.

The rate of return on equity of the group is 8 percentage points higher than the industry average, a little lower than the same period of the last year. The DuPont analysis method can be used to analyze the change of net assets yield:

Table 5.2. The Rate of Return on Equity

\begin{tabular}{llll}
\hline Year & 2016 & 2015 & 2014 \\
\hline Return on equity & $15.48 \%$ & $15.51 \%$ & $14.66 \%$ \\
Net profit margin on & $10.85 \%$ & $9.96 \%$ & $9.99 \%$ \\
sales & 0.82 & 0.86 & 0.80 \\
Total assets turnover & 1.48 & 1.68 & 1.80 \\
Equity multiplier & 1.48 & Eq
\end{tabular}

The promotion of the Equity multiplier is more obvious for the reduction of ROE. The Equity multiplier reflects the financial leverage of a company. In the first year of the scheme, there was a dramatic decline in the Equity multiplier, indicating that the capital structure of the company had been improved. Even at the stage where the company size is expanding at a high speed, the capital structure was being reasonably allocated. Livzon group actively utilized equity capital to create wealth, de-leveraging by means of issuing stocks instead of borrowing, and reducing the proportion of debt financing at the cost of operating costs. The net operating profit margin increased year by year, especially when the industry average is in a state of loss. It shows that the executives attach great importance to risks control and compliance management in order to creative profit maximization of every asset under the premise of reasonable control of financial risk.

\subsection{Market Performance}

\subsubsection{Cumulative Abnormal Return (CAR)}

According to the efficient market hypothesis, the market covers all information. The performance of a listed company can be reflected by its stock price. As China's stock market is not a strong and effective one, the length of selected period would affect the accuracy of the results. This paper chooses the grant date, the first unlock period and the second unlock period as datum point, the SZSE Component Index as the market index, and $[-3,+3] 、[-5,+5],[-7$, $+7]$ as window period to calculate the Cumulative Abnormal Return (CAR).

Table 5.3. Cumulative Abnormal Return (CAR)

\begin{tabular}{llll}
\hline Window period & {$[-3,+3]$} & {$[-5,+5]$} & {$[-7,+7]$} \\
\hline Grant date & $7.03 \%$ & $6.13 \%$ & $11.35 \%$ \\
First unlock & $-0.20 \%$ & $-0.07 \%$ & $-0.17 \%$ \\
Second unlock & $5.46 \%$ & $5.92 \%$ & $5.65 \%$ \\
\hline
\end{tabular}

According to Table 5-3, during the three window periods of the restricted stock grant, the cumulative excess return rate was over 6\%, and that of the second unlock days was over 5\%, which indicates that the market had approved the equity incentive plan of Livzon group. During the three window periods of the first unlock days, Livzon group's cumulative excess return rate was slightly inferior to the market, and this paper believes that it is because of the stock market crash of the second half of 2015, which affected the investors' sentiment. Apart from that the investor risk aversion is heavy, the downtown pressure on China's macro economy had increased in the first half of 2016, making stock market or industry leading more favored funds.

\subsubsection{Rate of Return on Investment}

Equity incentive is a solution for enterprises to solve the principal-agent problem and encourage the $\mathrm{R} \& \mathrm{D}$ enthusiasm of core technology personnel. It is a long-term incentive for the company's development. The cumulative excess return can temporarily reflect the degree of recognition of the market to the implementation of the scheme, and the return on investment reflects the long-term value and future development ability of the company as well as whether the equity incentive plan can really improve the company's financial performance and business performance.

Due to the intense turbulence of the stock market in 2015, the return on investment of a single firm cannot accurately reflect its intrinsic value, which needs to be adjusted through market comparison. 


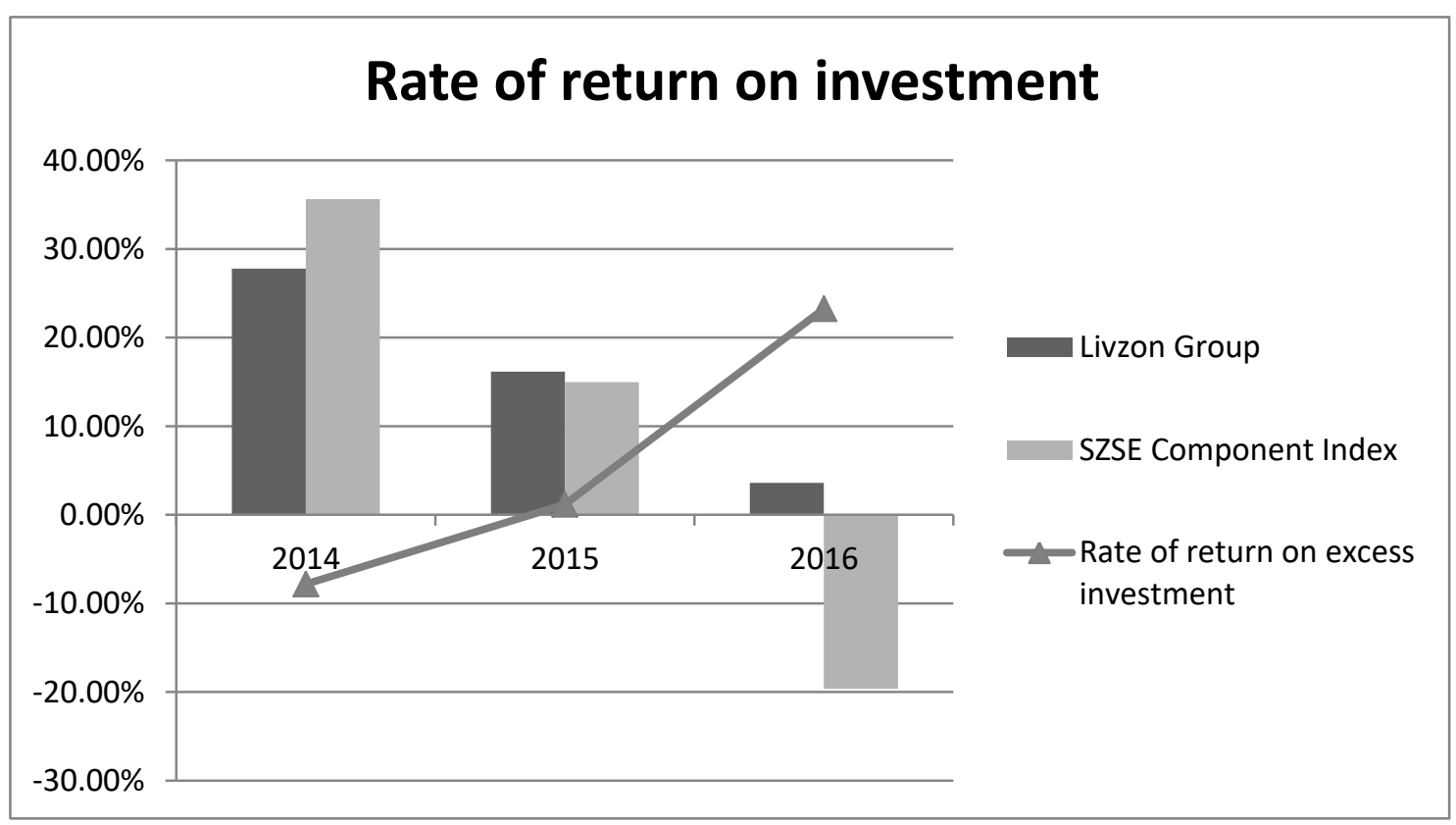

Figure 5.1. Rate of Return on Investment

It can be seen from the graph that from 2014 to 2016, although the rate of return on investment continues to decline, excluding the impact of market environment, the rate of return on excess investment is rising, indicating that the implementation of equity incentive scheme empowered the company a stronger resistance to external market risk and enabled it to perform well under a continuously sluggish economic environment. This shows that the company has great prospects and has long-term investment value.

\section{Conclusions}

(1) Livzon group belongs to the technology intensive industry, which means that the innovation and creativeness of core technology personnel could largely affect the development direction and position of the company among peer competitors. Granting the core staffs restricted stocks, in accordance with performance appraisal standards, can fully motivate them in the research and development of new technologies and the production of new products. Encouraging core technicians to fulfill the performance appraisal standards and unlock restricted stocks can guarantee the company to maintain a steady growth in performance under the negative profit level.

(2) Whether the principal-agent problem can be solved effectively is also reflected through the behavior of the manager. In the year of 2016, Livzon group's financial costs had dropped significantly. This is not only because that as a reputable company it can issue of ultrashort-term financing bonds to raise funds, the bigger reason is that the executives highlight the reasonable allocation of capital structure. Therefore, the capacity to motivate the Company Management to manage the company and control the financial risks from the perspectives of the shareholders is one of the prerequisites of the incentive scheme's efficiency.

\section{Policy Suggestions}

\subsection{Government Level}

\subsubsection{Improve the Income Tax Policy of Equity Incentive}

Among all the Zhuhai listed company implemented the equity incentive plan, high-tech enterprises account for the vast majority. High-tech industries also occupy a space in the industry development and strategic layout of Zhuhai City. Whether the implementation of equity incentive plan is effective or not greatly affects the company's ability to innovate and develop products, to maintain the core competitiveness and a healthy and rapid development. The relevant departments in Zhuhai are supposed to create a good policy environment, to formulate relevant preferential tax policies such as remitting or deferring personal income tax of restricted stock and stock options, to encourage high-tech enterprises to stimulate their employees' enthusiasm of independent innovation by means of equity incentive, to improve the technological innovation capability of enterprises. 


\subsubsection{Improve the Supervision System of the Securities Market}

The stock price of the secondary market reflects the effectiveness of the equity incentive plan of the listed companies. If the market is optimistic about the plan, it will pull up the stock price. After that, the yield of the listed company will exceed that of the market. If the market sentiment is slow, the market will not be optimistic about the implementation plan of the listed company.

Whether the secondary market can effectively reflect the excess returns of the listed companies depends largely on the perfection of the market supervision system. If the regulation is not perfect, there may exist of abnormal behavior like insider trading and price manipulation, which indirectly affect the accuracy of the stock price reflecting the intrinsic value of listed companies. Therefore, the government related departments should improve the norms and guidelines of secondary market regulations, enforce strict supervision on trading behavior and improve the regulatory system of securities market.

\subsection{Enterprise Level}

\subsubsection{Improve the Driving Power Index}

In Livzon group's equity incentive plan, one obvious defect is that the performance evaluation index is too single. The financial performance evaluation index just refers to one accounting index, the net profit growth rate. This is just a preliminary judgment on the profitability of the company. Other aspects such as the operational efficiency and development ability are not setting the staff assessment conditions. So, the setting of the examination is not comprehensive, which weakens the effectiveness of the equity incentive plan. Therefore, the company should pay attention to the design of incentive evaluation index and enrich the financial appraisal index to pursue a multifarious and comprehensive incentive exercise index when developing the equity incentive plans. At the same time, they should consider introducing the non-financial evaluation index into the evaluation mechanism, to ensure the evaluation result is true and effective.

\subsubsection{Set up Validity Period Reasonably}

The validity period set by the equity incentive scheme of the Livzon group is 5 years. The interval between each unlocking period is at least one year. Too long of the validity period is not conducive to the long-term planning of the company, because the market trend is changeable and the long validity period makes the company unable to transform its internal governance and external business strategy according to the market demand. But if the validity period is too short, the company would find it difficult to form a long-term incentive to employees, because multiple unlock times are helpful for forming a long-term and uninterrupted incentive to the enthusiasm of the staff, and in a relatively longer period of time the company can better measure the performance of staff and prevent opportunistic personnel make false to the performance.

\subsubsection{Maintain the Reasonable Control of the Large Shareholders to the Company}

Since the year of 2002 (when Joincare earned the control over Livzon group), to the year of 2006, the shareholding ratio of the largest shareholder, Joincare, had remained between 20\%-30\%. Although there was a gradually declining trend, compared to other big shareholders of Livzon group, the control power of Joincare was increasing. The strong control over the company motivates the major shareholders to tie their interest to the company's interests, make every effort to make the business policy and investment plan in line with the long-term development goals and market needs of the company. This would also encourage the major shareholders to implement equity incentive plan to motivate the core technical staffs' working and creative enthusiasm talent to drive innovation, innovation to boost demand, the demand to improve performance, achieve the maximization of shareholder wealth. But if the proportion of the first largest shareholder is too high, the largest shareholder may be "tunneling" company assets embezzling the interests of small and medium-sized shareholders together with the management. By contrast, if the shareholding ratio is too low, the equity would be highly dispersed, which means that there will be little relevance between the interest of shareholders and the interest of company. As a result, neither will shareholders be concerned of the internal demands and external opportunities of the development of the company, nor will they make strategic plans in accordance with the company's long-term development goals.

\subsubsection{Set up Reasonable Internal Structure of the Board of Directors}

The Board of Directors of Livzon Group consists of 11 members, including 8 non-executive directors (to ensure that the resolution of the board of directors is consistent with the interests of all shareholders), and a set of highly educated talents in fields of accounting, law, medicine, chemistry and so on. They have not only profound professional knowledge, but also a rich working experience. Together they serve as a guarantee for that the decision made by the board of directors not only compliance with the goal of maximizing the interests of shareholders but also is legal compliance and in accordance with the company's development direction and characteristics. On the other hand, 
oversize of the board will cause a sharp increase in the cost of finance and bring about contradictions between the internal staff and organization. Therefore, we should reasonably arrange the disposition of the board members, at the same time control the overall size of the board.

7.2.5 Give Full Play to the External Supervision Function of the Audit Institution

Livzon Group selected Ruihua CPA as its external auditor, considering the professional and authoritative of Ruihua. The company executives are unable to make the collusion with external auditors to make false accounts "empty" of the assets of the company. External audit institutions can make up for the lack of internal supervision and evaluate them objectively and fairly. Therefore, they can monitor whether the behavior of executives is against the interests of shareholders and promote the effective implementation of equity incentive plans.

\section{References}

Aboody, E., \& Johnson, B. W., \& Kasznik, R. (2010). Managerial behavior, agent costs and ownership structure. Journal of Financial Economics, 3(4), 305-360.

Bengt, H. (1979). Moral Hazard and Observability. The Bell Journal of Economics, 10(1), 74-91. https://doi.org/10.2307/3003320

Biao, C., \& Jianxin, L. (2015). The influence of equity incentive mechanism on the performance of Chinese listed companies. Operations and Fuzzy Science, 5(2), 23-29. https://doi.org/10.12677/ORF.2015.52004

Carl, S. (2013). CEO risk incentives and firm performance following R\&D increases.Journal of Banking and Finance, (37), 1176-1194.

Christoph, K., \& Benjamin, M. (2012). Insider ownership and corporate performance: evidence from Germany. Review of Managerial Science, (21), 145-156.

Hao, L., \& Zheng, S. (2009). A summary of the research on the western Equity incentive contract structure-- and the inspiration from equity incentive system of listed companies in China. Business Management, 31(04), 166-172.

Jinping, S., \& Jili, L., \& Ying, H. (2014). An empirical study on the relationship between equity incentive and corporate performance in the listed companies. Management Manager, (03), 9-11.

Ming, L., \& Xia, H. (2017). An empirical study on the incentive effect of employees' stock ownership . Accounting Newsletter, (6), 101-104.

Palia, D., \& Lichtenberg, F. (1999). Managerial ownership and firm performance: A re-examination using productivity measurement. Journal of Corporate Finance, 5(4), 323-339. https://doi.org/10.1016/S0929-1199(99)00009-7

Paul, O., \& Scott, S. (2012). Why do some firms give stock options to all employees: An empirical examination of alternative theories.Journal of Financial Economics, 76(1), 99-133.

Wenzhong, Z. (2016). An empirical study on the influence of equity incentive on the performances of enterprises. Rural Economy and Science and Technology, 27(2), 81-87.

\section{Copyrights}

Copyright for this article is retained by the author(s), with first publication rights granted to the journal.

This is an open-access article distributed under the terms and conditions of the Creative Commons Attribution license which permits unrestricted use, distribution, and reproduction in any medium, provided the original work is properly cited. 